OPEN ACCESS

Edited by:

Clara Mendoza-Lera,

University of Koblenz

Landau, Germany

Reviewed by:

Jacob Diamond,

INRAE Clermont-Auvergne-Rhône-

Alpes, France

Enrico Bonanno,

Luxembourg Institute of Science and

Technology, Luxembourg Kieran Khamis,

University of Birmingham United Kingdom

*Correspondence:

Stefan W. Ploum

swploum@gmail.com

Specialty section:

This article was submitted to

Water and Critical Zone,

a section of the journal

Frontiers in Water

Received: 17 February 2021

Accepted: 21 June 2021

Published: 30 July 2021

Citation:

Ploum SW, Leach JA, Laudon H and Kuglerová L (2021) Groundwater, Soil, and Vegetation Interactions at Discrete Riparian Inflow Points (DRIPS) and Implications for Boreal Streams.

Front. Water 3:669007.

doi: 10.3389/frwa.2021.669007

\section{Groundwater, Soil, and Vegetation Interactions at Discrete Riparian Inflow Points (DRIPs) and Implications for Boreal Streams}

\author{
Stefan W. Ploum ${ }^{1 *}$, Jason A. Leach ${ }^{2,3}$, Hjalmar Laudon ${ }^{1}$ and Lenka Kuglerová ${ }^{1}$ \\ ${ }^{1}$ Department of Forest Ecology and Management, Swedish University of Agricultural Sciences, Umeå, Sweden, ${ }^{2}$ Natural \\ Resources Canada, Canadian Forest Service, Sault Ste. Marie, ON, Canada, ${ }^{3}$ Environmental and Life Sciences Graduate \\ Program, Trent University, Peterborough, ON, Canada
}

Hydrological processes at hillslope and catchment scales explain a large part of stream chemistry dynamics through source-transport mechanisms from terrestrial to aquatic ecosystems. Riparian zones play a central role, as they exert a strong influence on the chemical signature of groundwater discharge to streams. Especially important are riparian areas where upslope subsurface flow paths converge, because they connect a large part of the catchment to a narrow section of the stream. Recent research shows that both in terrestrial and aquatic ecosystems, riparian convergence zones fulfill important biogeochemical functions that differ from surrounding riparian zones. Most catchment-scale conceptual frameworks focus on generalized hillslope-riparian-stream transects and do not explicitly consider riparian convergence zones. This study integrates collective work on hydrology, groundwater chemistry, vegetation and soils of discrete riparian inflow points (DRIPs) in a boreal landscape. We show that compared to adjacent riparian forests, DRIPs have groundwater levels that are consistently near the surface, and supply organic-rich water to streams. We suggest that interactions between hydrology, wetland vegetation, and peat soil development that occur in DRIPs leads to their unique groundwater chemistry and runoff dynamics. Stream-based studies show that across flow conditions, groundwater inputs from DRIPs to headwater reaches influence stream temperature, water chemistry and biology. As such, accounting for DRIPs can complement existing hillslope and stream observations, which would allow better representation of chemical and biological interactions associated with convergence of subsurface flow paths in riparian zones.

Keywords: riparian, stream, biogeochemistry, vegetation, drip, groundwater, peat, forest

\section{INTRODUCTION}

\section{Riparian Groundwater Inputs to Streams}

Riparian zones, or near-stream areas, are terrestrial interfaces that control groundwater (GW) inputs to streams (Cirmo and McDonnell, 1997). The riparian zone (RZ) can regulate nutrient leaching, and the transport of sediments, pollutants and heavy metals from terrestrial to aquatic ecosystems (Li et al., 2009; Stutter et al., 2012; Harms and Ludwig, 2016). These 
biogeochemical functions vary along reaches, mostly because riparian soil wetness regimes are spatially heterogeneous (Vidon, 2017). Soil wetness conditions in the RZ are strongly coupled to subsurface flow paths in the upslope contributing area (Beven and Kirkby, 1979; McGlynn and McDonnell, 2003). Converging flow paths to a focal point in the $\mathrm{RZ}$ can lead to extensive saturated areas, which can quickly generate runoff during rainfall events (Ambroise, 2004; Klaus and Jackson, 2018). It has been demonstrated that these particular sections of the RZ have runoff responses characterized by sustained saturation excess overland flow, and high runoff rates of event water (Scheliga et al., 2018). As such, riparian water residence times can episodically reduce, affecting the regulating chemical role that is characteristic for RZs (Jencso et al., 2010). This means that small sections of the RZ, where GW flow paths converge, can exert a disproportionally large control on stream water chemistry, supplying water that chemically deviates from the rest of the RZ (Allaire et al., 2015; Hester and Fox, 2020). To account for the role of discrete GW inputs in catchment biogeochemistry, there is a need characterize them (Briggs and Hare, 2018). Moreover, for quantitative stream water frameworks and landscape management practices, it is vital to conceptualize discrete GW inputs to streams, alongside existing hillslope and catchment concepts (Jencso et al., 2009).

\section{Boreal Riparian Zones}

In Swedish boreal landscapes, the source-transport mechanisms in riparian zones have been studied for over 30 years (Bishop et al., 1990). The cold and generally wet climate, in combination with shallow GW levels, promote peat accumulation in nearstream areas (Seibert et al., 2007). The development of highly conductive peat-rich top soils overlaying relatively low conductivity mineral soils, results in a vertical exponential hydraulic profile (Rodhe, 1989). During rain or snowmelt events, GW levels rise and lateral transport rates can rapidly increase from mm/d to m/d (Seibert et al., 2009; Bishop et al., 2011). This transmissivity feedback has helped explain rapid mobilization of pre-event water during flood episodes (Kirchner, 2003; Bishop et al., 2004), as well as the positive relationship between flow and dissolved organic carbon (DOC) observed in boreal forest streams (Laudon et al., 2011). However, this approach generally does not account for spatial heterogeneity of riparian GW inputs and the coupling with chemical dynamics (Burt, 2005; Vidon, 2017). Hillslope studies have shown that riparian organic layer thickness, depth to GW, and topography-driven flow path convergence account for much of the spatial heterogeneity observed in runoff generation from the RZ to streams (Lyon et al., 2011; Grabs et al., 2012; Ledesma et al., 2018a). Despite these advances in understanding spatiotemporal variability of sourcetransport mechanisms in RZs, catchment-integrative frameworks based riparian soil water chemistry still struggle to represent spatial and temporal dynamics of stream chemistry (Seibert et al., 2009).

\section{Problem Description and Research Aim}

Current source-transport concepts do not fully represent riparian heterogeneity in GW regimes, vegetation patterns and soil development associated with flow path convergence.
Moreover, the implications of focused GW discharge on stream biogeochemistry is poorly conceptualized within existing catchment frameworks (Briggs and Hare, 2018). This study focuses on discrete riparian inflow points, or DRIPs (Ploum et al., 2018), which are riparian areas that connect relatively large upslope contributing areas - UCA - (between 20,000 and $100,000 \mathrm{~m}^{2}$ ) to narrow sections of boreal streams. DRIPs have been largely overlooked, or misclassified as temporary streams. For example, hillslope studies have mostly focused on RZs with UCAs ranging from 10 to $1,000 \mathrm{~m}^{2}$ (Grabs et al., 2012; Lidman et al., 2017), while others have considered DRIPs as a dynamic component of the stream channel network (Ågren et al., 2015). Even though contributing areas of DRIPs approach stream initiation thresholds, they lack a confined stream channel and their appearance can be better described as a wetland-like corridor with riparian vegetation dominated by peat moss and GW levels near the surface (Jansson et al., 2007; Kuglerová et al., 2014a). We argue that these local shifts from forest hydrology to wetland-like hydrology within boreal catchments has implications for source-transport mechanisms that affect stream biogeochemistry dynamics (Laudon et al., 2011; Laudon and Sponseller, 2018). The aim of this study is to show that interactions among hydrology, GW chemistry and vegetation patterns at DRIPs lead to different riparian inputs to streams than surrounding RZ. Furthermore, we address the implications for streams and how monitoring DRIPs can improve catchment biogeochemistry frameworks. Our perspectives presented here are strongly informed by our work and collective time spent at boreal headwaters at the Krycklan Study Catchment in Sweden (Laudon et al., 2021).

\section{OBSERVATIONS}

DRIPS, also documented as GW discharge zones or discrete GW inputs, were visually identified along streams by their peatmoss and grass dominated vegetation community (Jansson et al., 2007; Kuglerová et al., 2014a), and high soil wetness relative to the rest of the RZ (Figure 1C). A priori identification of DRIPs involved selection of RZs with relatively large UCAs (Figure 1B), as these were areas where GW was expected to discharge to the stream (Kuglerová et al., 2014a). Combined with the "squishy boot" approach (Dunne et al., 1975) soil wetness conditions along and away from streams were delineated (Ågren et al., 2014). A monitoring network was setup with the main focus on the C5C6 stream reach in Krycklan (Figure 1A), which sources from a headwater lake and flows through forest to a hydrometric station $1.5 \mathrm{~km}$ downstream (Laudon et al., 2021). A GW wellnetwork was setup in the riparian zone (Ploum et al., 2020), and a fiber-optic distributed temperature sensing (FO-DTS) cable was installed in stream (Leach et al., 2017). In addition, repeated stream water sampling was done at 50 meter intervals along the stream reach (Lupon et al., 2019).

\section{Hydrology}

DRIPs have a distinct hydrological behavior, characterized by sustained GW-stream connections and quick responses to rain and snowmelt inputs. DRIPs have relatively constant GW 

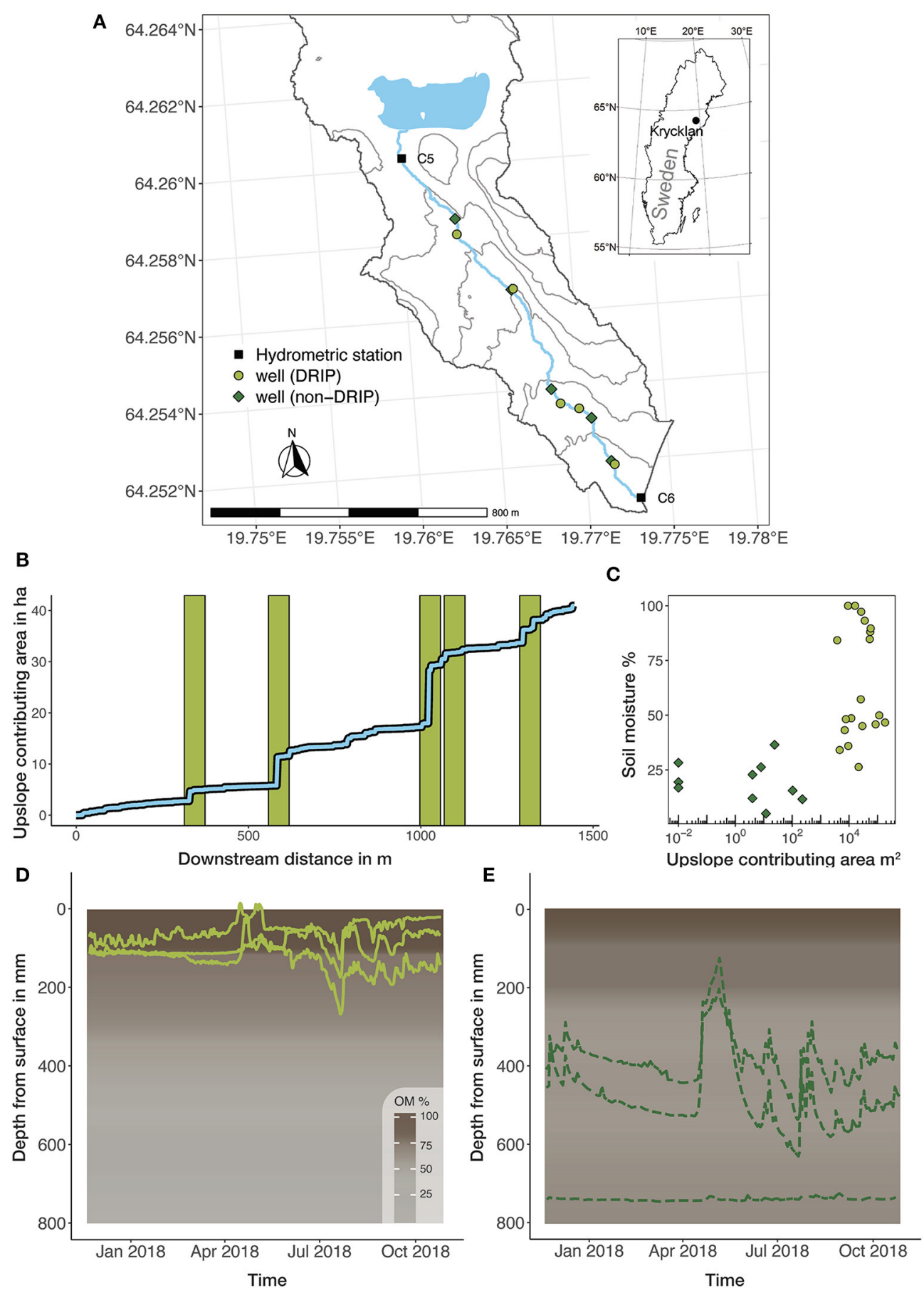

FIGURE 1 | DRIPs along the C5-C6 headwater reach. (A) shows an inset map of Krycklan in Sweden and the C6 catchment. Hydrometric stations C5 and C6 are indicated by black squares, and DRIP and non-DRIP wells are indicated in light green circles and dark green spades, respectively. (B) shows in light blue the gain in upslope contributing area along the stream reach, from C5 to C6. The light green vertical bars show the approximate location of the DRIPs along the reach. (C) shows a summer snapshot of soil moisture percentage of DRIPs and non-DRIPs across the Krycklan catchment relative to their upslope contributing area. (D) shows daily time-series of depth to groundwater from three DRIP wells during the hydrological year 2018. The background shows a color gradient from dark brown to gray that represents the $10 \mathrm{~cm}$ aggregated mean organic matter percentage $(\mathrm{OM} \%)$ from DRIPs $(n=12)$. (E) shows in a similar fashion the depth to groundwater from three non-DRIP wells, and the OM\% of non-DRIPs $(n=12)$.

levels close to the surface (Figure 1D), while the surrounding RZ has deeper GW levels which periodically rise toward the surface in response to rain or snowmelt inputs (Figure 1E).
This demonstrates that DRIPs facilitate a permanent GW connection between the upland landscape and the stream network. Even during extreme drought conditions, sustained 


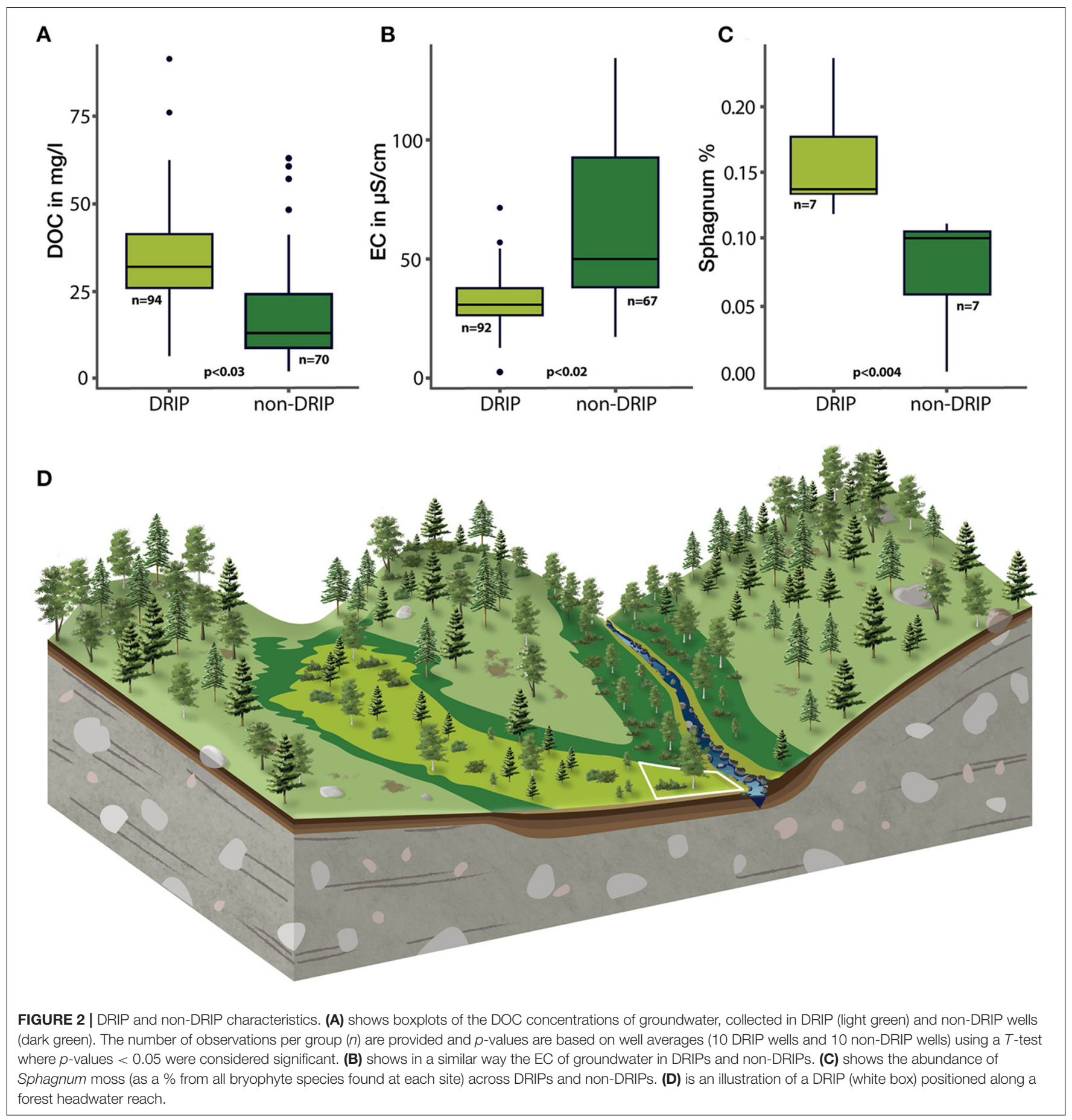

GW-stream connections at DRIPs have been documented, while along the rest of the stream all lateral inputs had ceased (Gómez-Gener et al., 2020). During rain or snowmelt events, the combination of the large contributing area of DRIPs (Figure 1B), and the near-surface GW levels promote most of the event water to rapidly route toward the stream, via flow paths near - and sometimes over - the soil surface. Distributed manual discharge measurements along the study reach highlight that across a range of flow conditions, the majority of gained streamflow enters the stream through DRIPs (Lupon et al., 2019). Moreover, shifting stable water isotope signatures associated with rainfall events indicate that event water was present in DRIP groundwater directly next to the stream (Leach et al., 2017). During snowmelt episodes, ice sheets have been observed at DRIPs, which routed meltwater over the ice surface, bypassing riparian soils (Ploum et al., 2018). These observations show that DRIPs differ from the more broadly applied transmissivity feedback concept, which mostly emphasizes the rise of GW levels into highly conductive 
soil layers, which leads to mobilization of pre-event water (Bishop et al., 1990).

\section{Groundwater Chemistry}

The contrasting hydrological regimes of DRIPs and non-DRIPs lead to differences in GW chemistry. The near-surface flow paths at DRIPs route a portion of GW flow through peat or living moss layers, while in non-DRIPs solutes from various soil layers are mobilized in response to GW level variation (Ledesma et al., 2018a). As a result, DOC concentrations in DRIPs are on average 1.7 times higher $(34 \mathrm{mg} / \mathrm{l})$ compared to non-DRIPs $(20 \mathrm{mg} / \mathrm{l}$, Figure 2A). However, during snowmelt events in spring, DOC concentrations in DRIPs decrease by 20\% (Ploum et al., 2020), which can be explained by periods of overland or over-ice flow (Figure 1D). Further, the low electrical conductivity (EC) in DRIP wells $(36 \mu \mathrm{S} / \mathrm{cm})$ compared to non-DRIPs $(52 \mu \mathrm{S} / \mathrm{cm})$ suggests that most GW in DRIPs has little interaction with the mineral soil (Figure 2B). Moreover, the greater variability in EC at non-DRIPs supports the idea that in these parts of the RZ GW levels fluctuate across soil horizons with varying organic and mineral fractions (Figure 1E). The $20 \%$ increase in DOC at nonDRIPs during snowmelt (Ploum et al., 2020) further supports the idea that non-DRIP groundwater chemistry is highly dependent on GW level fluctuation. In non-DRIPs a distinct change in chemistry can be observed within the RZ toward the stream (Ploum et al., 2020), which corroborates that at non-DRIPs the areas upslope of the RZ have minor influence on riparian water chemistry (Ledesma et al., 2018a). In contrast, the distinct DOC and EC concentrations of DRIPs is observed at the upslope extent of the RZ. This suggests that for the chemical signature of DRIP groundwater, the wetland-like corridor upslope of the RZ plays an important role. The lateral transport of water through peat and living moss near the surface, allows event water to be enriched with DOC. This indicates that in terms of hydrology and GW chemistry, DRIPs might be better represented by wetland-derived explanatory frameworks rather than forest hydrology concepts (Laudon et al., 2011).

\section{Vegetation and Soil Conditions}

DRIPs and their upslope contributing area look like wetland corridors hidden in the forest (Figure 2D). DRIPs have higher species richness of vascular plants, with several unique species typical to wetland-type communities, which contrast with the typical non-DRIP riparian forest vegetation (Kuglerová et al., 2014a). Moreover, DRIPs seem to increase the lateral extent of riparian vegetation occurrence beyond the width found along neighboring non-DRIP riparian zones (Kuglerová et al., 2016). The higher species richness of plants as well as the increased lateral distance of riparian communities at DRIPs have been primarily connected to the unique soil biogeochemical conditions, such as higher soil $\mathrm{pH}$, higher amount of available nitrogen, and faster mineralization and plant uptake (Kuglerová et al., 2014a). Tiwari et al. (2016) further showed that tree composition in DRIPs is dominated by deciduous species, while coniferous are more common in non-DRIPs. In addition, tree growth in DRIPs is limited by lower soil oxygen availability to roots due to frequent saturated soil conditions. The saturated soil conditions are favorable for the growth of peat mosses (Sphagnum sp.), which have higher abundance at DRIPs compared to adjacent non-DRIPs (Figure 2C). Further, the process of organic matter decomposition is slower at DRIPs. This was visible from soil inventories along the riparian GW well-network, which showed that while non-DRIPs had darker, strongly decomposed organic horizons, the upper $25 \mathrm{~cm}$ of DRIP soils consist mostly of undecomposed Sphagnum moss (Supplementary Figure 1). These Sphagnum top soils have been reported to facilitate lateral water movements at rates in the order of $800 \mathrm{~m} / \mathrm{d}$ (van Breemen, 1995). Combined with the persistent near-surface GW levels, DRIPs can rapidly move event water to the stream compared to non-DRIP locations.

\section{INTERACTIONS}

Our observations suggest that within the UCA of DRIPs, interactions among hydrological and chemical soil conditions and vegetation lead to the development of a wetland-like corridor within the forest. The convergence of subsurface flow paths at DRIPs leads to saturated soil conditions, and subsequently DRIPs are dominated by Sphagnum mosses. Over time, peat develops, which results in soil biogeochemical conditions that sustain these vegetation patterns that contrast with the surrounding forest. The peat topsoil and near-surface GW levels route water through peat and living moss, resulting in supply of organic-rich water to streams. Furthermore, the saturated conditions promote the mobilization of newly introduced rain and snowmelt water during events. Meanwhile during such events, surrounding nonDRIP RZ become activated, leading to rapid mobilization of preevent water. These contrasting runoff generation processes then lead to a mosaic of lateral inputs to streams, affecting spatial patterns of stream biogeochemistry.

The primary driver of these interactions in DRIPs is landscape topography. DRIPs have UCAs close to stream channel initiation thresholds $(10 \mathrm{ha})$, but they are not characterized by defined stream channels. While in warmer climates or steeper terrain, these parts of the landscape are often approached as stream channels with intermittent open-water flow (Hale and Godsey, 2019; Prancevic and Kirchner, 2019), in the cold and less steep boreal landscape we found wetland-like corridors. We consider that this is the result of climate-vegetation-soil interactions (Troch et al., 2013) specific to the boreal region: the cold climate, short growing season and saturated soil conditions lead to peat formation in topographic lows. In a similar climate setting, it has been shown that hydrology-vegetation interactions lead to formation of treed wetlands in and around stream networks, and that these wetland features can strongly influence stream DOC concentrations (Creed et al., 2003; LittleDevito et al., 2019). Specifically, wetlands directly connected to stream networks can moderate peak flows and sustain low flows (Ameli and Creed, 2019). As such, DRIPs have a connecting function between the upland and the stream network (Figure 2D). Here, we showed that besides hydrological implications, there are soil and vegetation interactions that lead to distinctly different GW chemistry. Thus, the DRIP concept 
highlights the need to include vegetation in the delineation of open-channel networks, and account for hydrological and biogeochemical implications. To correctly represent sourcetransport processes from terrestrial to aquatic ecosystems, it is important to acknowledge differences between open-channel flow and subsurface flow through wetland-like corridors.

\section{IMPLICATIONS FOR STREAMS AND MONITORING}

DRIPs are not only important for source-transport mechanisms from terrestrial to aquatic ecosystems, but also have an important biogeochemical role for streams. DRIPs create variable streamflow conditions along the reach (Lupon et al., 2019; Gómez-Gener et al., 2020), and control stream temperature dynamics (Leach et al., 2021). Further, Lupon et al. (2019) demonstrated that directly downstream of DRIPs, the biological uptake of DOC increased, leading to enhanced emissions of methane and carbon dioxide across flow conditions. Also instream nitrogen uptake locally increased by presence of DRIPs (Lupon et al., 2020). This sheds new light on the idea that the main role of boreal headwaters in stream networks is the downstream supply of solutes (Raymond et al., 2016). Instead, headwaters not only transport DOC from hillslopes toward downstream reaches, but have a reactive role as well (Casas-Ruiz et al., 2017). More specifically, the DRIP concept facilitates the use of topography to identify stream reaches where large fluxes of DOC are transported from the terrestrial ecosystem to the aquatic ecosystem, and where reactive stream sections are located. This link between process understanding and a generally available tool can contribute to the scaling of supply and removal mechanisms of terrestrial DOC across stream networks (Mineau et al., 2016).

The explicit consideration of discrete GW contributions in stream chemistry frameworks is a timely issue (Briggs and Hare, 2018). So far, features such as DRIPs are poorly represented in environmental monitoring infrastructure and are therefore likely to be misclassified. We consider the DRIP concept to be a useful to further promote the consideration of flow path convergence in study designs (Burt, 2005). Including DRIPs in existing frameworks on hillslope and catchment scale can give new insights in catchment processes (Seibert et al., 2009; Ledesma et al., 2018b). We also consider that identification of DRIPs along stream networks is of interest for scaling biogeochemical dynamics across boreal landscapes (Laudon and Sponseller, 2018). Further, we argue that the DRIP concept can help implementation of riparian complexity in land management practices (Kuglerová et al., 2014b; Wallace et al., 2018). This can be facilitated by combining the process understanding of DRIPs with soil wetness maps (Lidberg et al., 2020), which can be used to identify vulnerable riparian areas that need to be protected from anthropogenic disturbance (Kuglerová et al., 2014b).

\section{DATA AVAILABILITY STATEMENT}

The datasets presented in this study can be found in online repositories. The names of the repository/repositories and accession number(s) can be found below: https://www. safedeposit.se/projects/51.

\section{AUTHOR CONTRIBUTIONS}

SP collected and analyzed data, wrote the majority of the text, and produced the figures. JL collected and provided spatial data for analysis, and contributed to discussion and text revisions. HL contributed to discussion and text revisions. LK setup the groundwater monitoring network, collected and analyzed vegetation data, and contributed to discussion and text revisions. All authors contributed to the article and approved the submitted version.

\section{FUNDING}

This research was supported by the Oscar and Lili Lamm Foundation, and the Swedish Research Council Formas (grant no. 2015-00531).

\section{ACKNOWLEDGMENTS}

We acknowledge the technical support of SLU laboratory staff and the Svartberget research station. We thank Andrés PeraltaTapia for the well installation and Foeke Menting for soil sample collection. We thank Kelly Hondula for supporting data analysis in Rstudio, and Jasper Candel and Jelmer Nijp for discussing peat soils. Scientific illustration by Juliana Spahr, SciVisuals.com.

\section{SUPPLEMENTARY MATERIAL}

The Supplementary Material for this article can be found online at: https://www.frontiersin.org/articles/10.3389/frwa. 2021.669007/full\#supplementary-material

Supplementary Figure 1 | Top soils $(<30 \mathrm{~cm}$ ) of DRIPs and non-DRIPs. The upper row shows a set of five DRIPs, characterized by a living Sphagnum moss layer over a peat layer. The bottom row shows five non-DRIPs of mostly decomposed organic matter, and root material.

\section{REFERENCES}

Ågren, A., Lidberg, W., and Ring, E. (2015). Mapping temporal dynamics in a forest stream network-implications for riparian forest management. Forests 6, 2982-3001. doi: 10.3390/f6092982

Ågren, A., Lidberg, W., Strömgren, M., Ogilvie, J., and Arp, P. (2014). Evaluating digital terrain indices for soil wetness mapping-a Swedish case study. Hydrol. Earth Syst. Sci. 18, 3623-3634. doi: 10.5194/hess-18-3623-2014

Allaire, S. E., Sylvain, C., Lange, S. F., Thériault, G., and Lafrance, P. (2015). Potential efficiency of riparian vegetated buffer strips in intercepting soluble compounds in the presence of subsurface preferential flows, edited by J.-T. Li. PLoS ONE 10:e0131840. doi: 10.1371/journal.pone.0131840

Ambroise, B. (2004). Variable "active" versus "contributing" areas or periods: a necessary distinction. Hydrol. Process. 18, 1149-1155. doi: 10.1002/hyp.5536

Ameli, A. A., and Creed, I. F. (2019). Does wetland location matter when managing wetlands for watershed-scale flood and drought resilience?. 
J. Am. Water Resourc. Assoc. 55, 529-542. doi: 10.1111/1752-1688. 12737

Beven, K. J., and Kirkby, M. J. (1979). A physically based variable contributing area model of basin hydrology/Un modèle à base physique de zone d'appel variable de l'hydrologie du bassin versant. Hydrol. Sci. J. 24, 43-69. doi: $10.1080 / 02626667909491834$

Bishop, K., Grip, H., and O'neill, A. (1990). The origins of acid runoff in a hillslope during storm events. J. Hydrol. 116, 35-61. doi: 10.1016/0022-1694(90)90114-D

Bishop, K., Seibert, J., Köhler, S., and Laudon, H. (2004). Resolving the double paradox of rapidly mobilized old water with highly variable responses in runoff chemistry. Hydrol. Process. 18, 185-189. doi: 10.1002/hyp.5209

Bishop, K., Seibert, J., Nyberg, L., and Rodhe, A. (2011). Water storage in a till catchment. II: implications of transmissivity feedback for flow paths and turnover times. Hydrol. Process. 25, 3950-3959. doi: 10.1002/hyp. 8355

Briggs, M. A., and Hare, D. K. (2018). Explicit consideration of preferential groundwater discharges as surface water ecosystem control points. Hydrol. Process. 32, 2435-2440. doi: 10.1002/hyp.13178

Burt, T. P. (2005). A third paradox in catchment hydrology and biogeochemistry: decoupling in the riparian zone. Hydrol. Process. 19, 2087-2089. doi: 10.1002/hyp.5904

Casas-Ruiz, J. P., Catalán, N., Gómez-Gener, L., Schiller, D., von, Obrador, B., Kothawala, D. N., et al. (2017). A tale of pipes and reactors: Controls on the in-stream dynamics of dissolved organic matter in rivers. Limnol. Oceanogr. 62, S85-94. doi: 10.1002/lno.10471

Cirmo, C. P., and McDonnell, J. J. (1997). Linking the hydrologic and biogeochemical controls of nitrogen transport in near-stream zones of temperate-forested catchments: a review. J. Hydrol. 199, 88-120. doi: 10.1016/S0022-1694(96)03286-6

Creed, I., Sanford, S., Beall, F., Molot, L., and Dillon, P. (2003). Cryptic wetlands: integrating hidden wetlands in regression models of the export of dissolved organic carbon from forested landscapes. Hydrol. Process. 17, 3629-3648. doi: 10.1002/hyp.1357

Dunne, T., Moore, T., and Taylor, C. (1975). Recognition and prediction of runoff-producing zones in humid regions. Hydrol. Sci. Bull. 20, 305-327.

Gómez-Gener, L., Lupon, A., Laudon, H., and Sponseller, R. A. (2020). Drought alters the biogeochemistry of boreal stream networks. Nat. Commun. 11, 1-11. doi: 10.1038/s41467-020-15496-2

Grabs, T., Bishop, K., Laudon, H., Lyon, S. W., and Seibert, J. (2012). Riparian zone hydrology and soil water total organic carbon (TOC): implications for spatial variability and upscaling of lateral riparian TOC exports. Biogeosciences 9, 3901-3916. doi: 10.5194/bg-9-3901-2012

Hale, R. L., and Godsey, S. E. (2019). Dynamic stream network intermittence explains emergent dissolved organic carbon chemostasis in headwaters. Hydrol. Process. 33, 1926-1936. doi: 10.1002/hyp.13455

Harms, T. K., and Ludwig, S. M. (2016). Retention and removal of nitrogen and phosphorus in saturated soils of arctic hillslopes. Biogeochemistry 127, 291-304. doi: 10.1007/s10533-016-0181-0

Hester, E. T., and Fox, G. A. (2020). Preferential flow in riparian groundwater: gateways for watershed solute transport and implications for water quality management. Water Resourc. Res. 56. doi: 10.1029/2020WR028186

Jansson, R., Laudon, H., Johansson, E., and Augspurger, C. (2007). The importance of groundwater discharge for plant species number in riparian zones. Ecology 88, 131-139. doi: 10.1890/0012-9658(2007)88[131:TIOGDF]2.0.CO;2

Jencso, K. G., McGlynn, B. L., Gooseff, M. N., Bencala, K. E., and Wondzell, S. M. (2010). Hillslope hydrologic connectivity controls riparian groundwater turnover: implications of catchment structure for riparian buffering and stream water sources. Water Resourc. Res. 46. doi: 10.1029/2009WR008818

Jencso, K. G., McGlynn, B. L., Gooseff, M. N., Wondzell, S. M., Bencala, K. E., and Marshall, L. A. (2009). Hydrologic connectivity between landscapes and streams: transferring reach-and plot-scale understanding to the catchment scale. Water Resourc. Res. 45. doi: 10.1029/2008WR007225

Kirchner, J. W. (2003). A double paradox in catchment hydrology and geochemistry. Hydrol. Process. 17, 871-874. doi: 10.1002/hyp.5108

Klaus, J., and Jackson, C. R. (2018). Interflow is not binary: a continuous shallow perched layer does not imply continuous connectivity. Water Resour. Res. 54, 5921-5932. doi: 10.1029/2018WR022920

Kuglerová, L., Ågren, A., Jansson, R., and Laudon, H. (2014b). Towards optimizing riparian buffer zones: ecological and biogeochemical implications for forest management. For. Ecol. Manag. 334, 74-84. doi: 10.1016/j.foreco.2014. 08.033

Kuglerová, L., Dynesius, M., Laudon, H., and Jansson, R. (2016). Relationships between plant assemblages and water flow across a boreal forest landscape: a comparison of liverworts. Mosses Vasc. Plants Ecosyst. 19, 170-184. doi: 10.1007/s10021-015-9927-0

Kuglerová, L., Jansson, R., Ågren, A., Laudon, H., and Malm-Renöfält, B. (2014a). Groundwater discharge creates hotspots of riparian plant species richness in a boreal forest stream network. Ecology 95, 715-725. doi: 10.1890/13-0363.1

Laudon, H., Berggren, M., Ågren, A., Buffam, I., Bishop, K., Grabs, T., et al. (2011). Patterns and dynamics of dissolved organic carbon (DOC) in boreal streams: the role of processes. Connect. Scal. Ecosyst. 14, 880-893. doi: 10.1007/s10021-011-9452-8

Laudon, H., Hasselquist, E. M., Peichl, M., Lindgren, K., Sponseller, R., Lidman, F., et al. (2021). Northern landscapes in transition: evidence, approach and ways forward using the Krycklan Catchment Study. Hydrol. Process. 35. doi: $10.1002 /$ hyp. 14170

Laudon, H., and Sponseller, R. A. (2018). How landscape organization and scale shape catchment hydrology and biogeochemistry: insights from a long-term catchment study. Wiley Interdiscip. Rev. Water 5:e1265. doi: 10.1002/wat2.1265

Leach, J., Lidberg, W., Kuglerov,á, L., Peralta-Tapia, A., Ågren, A., and Laudon, H. (2017). Evaluating topography-based predictions of shallow lateral groundwater discharge zones for a boreal lake-stream system. Water Resour. Res. 53, 5420-5437. doi: 10.1002/2016WR019804

Leach, J. A., Neilson, B. T., Buahin, C. A., Moore, R. D., and Laudon, H. (2021). Lake outflow and hillslope lateral inflows dictate thermal regimes of forested streams draining small lakes. Water Resourc. Res. 57, e2020WR028136. doi: 10.1029/2020WR028136

Ledesma, J., Kothawala, D. N., Bastviken, P., Maehder, S., Grabs, T., and Futter, M. (2018a). Stream dissolved organic matter composition reflects the riparian zone, not upslope soils in boreal forest headwaters. Water Resourc. Res. 54, 3896-3912. doi: 10.1029/2017WR021793

Ledesma, J. L., Futter, M. N., Blackburn, M., Lidman, F., Grabs, T., Sponseller, R. A., et al. (2018b). Towards an improved conceptualization of riparian zones in boreal forest headwaters. Ecosystems 21, 297-315. doi: $10.1007 /$ s10021-017-0149-5

Li, S., Gu, S., Tan, X., and Zhang, Q. (2009). Water quality in the upper Han River basin, China: the impacts of land use/land cover in riparian buffer zone. J. Hazard. Mater. 165, 317-324. doi: 10.1016/j.jhazmat.2008.09.123

Lidberg, W., Nilsson, M., and Ågren, A. (2020). Using machine learning to generate high-resolution wet area maps for planning forest management: A study in a boreal forest landscape. Ambio 49, 475-486. doi: 10.1007/s13280-019-01196-9

Lidman, F., Boily, Å., Laudon, H., and Köhler, S. J. (2017). From soil water to surface water-how the riparian zone controls element transport from a boreal forest to a stream. Biogeosciences 14:3001. doi: 10.5194/bg-14-3001-2017

Little-Devito, M., Mendoza, C. A., Chasmer, L., Kettridge, N., and Devito, K. J. (2019). Opportunistic wetland formation on reconstructed landforms in a subhumid climate: influence of site and landscape-scale factors. Wetlands Ecol. Manag. 27, 587-608. doi: 10.1007/s11273-019-09679-y

Lupon, A., Denfeld, B. A., Laudon, H., Leach, J., Karlsson, J., and Sponseller, R. A. (2019). Groundwater inflows control patterns and sources of greenhouse gas emissions from streams. Limnol. Oceanogr. 64, 1545-1557. doi: 10.1002/lno.11134

Lupon, A., Denfeld, B. A., Laudon, H., Leach, J., and Sponseller, R. A. (2020). Discrete groundwater inflows influence patterns of nitrogen uptake in a boreal headwater stream. Freshwater Sci. 39, 228-240. doi: 10.1086/708521

Lyon, S. W., Grabs, T., Laudon, H., Bishop, K. H., and Seibert, J. (2011). Variability of groundwater levels and total organic carbon in the riparian zone of a boreal catchment. J. Geophys. Res. Biogeosci. 116. doi: 10.1029/2010JG001452

McGlynn, B. L., and McDonnell, J. J. (2003). Quantifying the relative contributions of riparian and hillslope zones to catchment runoff. Water Resourc. Res. 39. doi: 10.1029/2003WR002091

Mineau, M. M., Wollheim, W. M., Buffam, I., Findlay, S. E. G., Hall, R. O., Hotchkiss, E. R., et al. (2016). Dissolved organic carbon uptake in streams: a review and assessment of reach-scale measurements. J. Geophys. Res. Biogeosciences 121, 2019-2029. doi: 10.1002/2015JG003204

Ploum, S. W., Laudon, H., Peralta-Tapia, A., and Kuglerov,á, L. (2020). Are dissolved organic carbon concentrations in riparian groundwater linked to 
hydrological pathways in the boreal forest? Hydrol. Earth Syst. Sci. 24, 1709-1720. doi: 10.5194/hess-24-1709-2020

Ploum, S. W., Leach, J. A., Kuglerová, L., and Laudon, H. (2018). Thermal detection of discrete riparian inflow points (DRIPs) during contrasting hydrological events. Hydrol. Process. 32, 3049-3050. doi: 10.1002/hyp. 13184

Prancevic, J. P., and Kirchner, J. W. (2019). Topographic controls on the extension and retraction of flowing streams. Geophys. Res. Lett. 46, 2084-2092. doi: 10.1029/2018GL081799

Raymond, P. A., Saiers, J. E., and Sobczak, W. V. (2016). Hydrological and biogeochemical controls on watershed dissolved organic matter transport: pulse-shunt concept. Ecology 97, 5-16. doi: 10.1890/14-1684.1

Rodhe, A. (1989). On the Generation of Stream Runoff in Till SoilsPaper presented at the Nordic Hydrological Conference (Rovaniemi. Finland, August-1988). Hydrol. Res. 20, 1-8. doi: 10.2166/nh.1989.0001

Scheliga, B., Tetzlaff, D., Nuetzmann, G., and Soulsby, C. (2018). Groundwater dynamics at the hillslope-riparian interface in a year with extreme winter rainfall. J. Hydrol. 564, 509-528. doi: 10.1016/j.jhydrol.2018.06.082

Seibert, J., Grabs, T., Köhler, S., Laudon, H., Winterdahl, M., and Bishop, K. (2009). Linking soil-and stream-water chemistry based on a Riparian FlowConcentration Integration Model. Hydrol. Earth Syst. Sci. 13, 2287-2297. doi: 10.5194/hess-13-2287-2009

Seibert, J., Stendahl, J., and Sørensen, R. (2007). Topographical influences on soil properties in boreal forests. Geoderma 141, 139-148. doi: 10.1016/j.geoderma.2007.05.013

Stutter, M. I., Chardon, W. J., and Kronvang, B. (2012). Riparian buffer strips as a multifunctional management tool in agricultural landscapes: introduction. $J$. Environ. Qual. 41, 297-303. doi: 10.2134/jeq2011.0439

Tiwari, T., Lundström, J., Kuglerová, L., Laudon, H., Öhman, K., and Ågren, A. (2016). Cost of riparian buffer zones: a comparison of hydrologically adapted site-specific riparian buffers with traditional fixed widths. Water Resour. Res. 52, 1056-1069. doi: 10.1002/2015WR018014
Troch, P. A., Carrillo, G., Sivapalan, M., Wagener, T., and Sawicz, K. (2013). Climate-vegetation-soil interactions and long-term hydrologic partitioning: signatures of catchment co-evolution. Hydrol. Earth Syst. Sci. 17, 2209-2217. doi: 10.5194/hess-17-2209-2013

van Breemen, N. (1995). How Sphagnum bogs down other plants. Trends Ecol. Evol. 10, 270-275. doi: 10.1016/0169-5347(95)90007-1

Vidon, P. G. (2017). Not all riparian zones are wetlands: understanding the limitation of the "wetland bias" problem. Hydrol. Process. 31, 2125-2127. doi: 10.1002/hyp.11153

Wallace, C., McCarty, G., Lee, S., Brooks, R., Veith, T., Kleinman, P., et al. (2018). Evaluating concentrated flowpaths in riparian forest buffer contributing areas using LiDAR imagery and topographic metrics. Remote Sens. 10:614. doi: $10.3390 /$ rs 10040614

Conflict of Interest: The authors declare that the research was conducted in the absence of any commercial or financial relationships that could be construed as a potential conflict of interest.

Publisher's Note: All claims expressed in this article are solely those of the authors and do not necessarily represent those of their affiliated organizations, or those of the publisher, the editors and the reviewers. Any product that may be evaluated in this article, or claim that may be made by its manufacturer, is not guaranteed or endorsed by the publisher.

Copyright $\odot 2021$ Ploum, Leach, Laudon and Kuglerová. This is an open-access article distributed under the terms of the Creative Commons Attribution License (CC $B Y)$. The use, distribution or reproduction in other forums is permitted, provided the original author(s) and the copyright owner(s) are credited and that the original publication in this journal is cited, in accordance with accepted academic practice. No use, distribution or reproduction is permitted which does not comply with these terms. 